Article

\title{
Landscape Transformation Influences Responses of Terrestrial Small Mammals to Land Use Intensity in North-Central Namibia
}

\author{
Nicole Starik ${ }^{1, *}$, Oskar Kandali Mbango ${ }^{2}$, Susanne Bengsch ${ }^{3}$, Thomas Göttert ${ }^{1}$ \\ and Ulrich Zeller ${ }^{1}$ \\ 1 Systematic Zoology Division, Humboldt-Universität zu Berlin, Unter den Linden 6, 10099 Berlin, Germany; \\ thomas.goettert@hu-berlin.de (T.G.); ulrich.zeller@hu-berlin.de (U.Z.) \\ 2 Department of Animal Science, University of Namibia, Windhoek 900, Namibia; ombango@unam.na \\ 3 Institute of Landscape Architecture and Environmental Planning, Technische Universität Berlin, \\ Str. des 17. Juni 145, 10623 Berlin, Germany; susanne.bengsch@stiftung-naturschutz.de \\ * Correspondence: nicole.starik@hu-berlin.de; Tel.: +49-(0)30 209346916
}

Received: 11 November 2020; Accepted: 18 December 2020; Published: 21 December 2020

\begin{abstract}
In this study, we investigate and compare the response patterns of small mammal communities to increasing land use intensity in two study areas: private farmland at the southern boundary of Etosha National Park and smallholder farmland in Tsumeb agricultural area. Species richness, community composition and a standardized capture index (RCI) are compared between sites of (a) increasing grazing pressure of ungulates (Etosha) and (b) increasing conversion of bushland to arable land (Tsumeb). Within each study area, we found clear response patterns towards increasing land use intensity. However, patterns differ significantly between the two areas. Within the less-transformed area (Etosha), high land use intensity results in a decrease in the RCI but not species richness. Small mammal communities remain relatively stable, but ecosystem functions (e.g., bioturbation, seed dispersal) are weakened. Within the more-transformed area (Tsumeb), high land use intensity leads to a decrease in species richness and increasing RCIs of two common pest species. The disappearance of a balanced community and the dramatic increase in a few pest species has the potential to threaten human livelihoods (e.g., crop damage, disease vectors). Our comparative approach clearly indicates that Gerbilliscus leucogaster is a possible candidate for an ecological indicator of ecosystem integrity. Mastomys natalensis has the potential to become an important pest species when bushland is transformed into irrigated arable land. Our results support the importance of area-specific conservation and management measures in savanna ecosystems.
\end{abstract}

Keywords: land use; livestock grazing; irrigation-based cropping; lucerne; ecological indicator; Gerbilliscus leucogaster; Etosha; rodent pest; Southern Africa

\section{Introduction}

African savannas are of high ecological relevance, but are also vulnerable to human-induced disturbances [1,2]. Owing to the agricultural potential of grassland systems and a growing human population, there is an increasing trend in the conversion of savanna ecosystems into profitable production systems for livestock or crop farming [3]. This can cause a dilemma between nature conservation and land use [4]. In Namibia, there is a trend to move towards a high performing economy and achieve food security by agricultural intensification [5]. For example, many efforts are being made to significantly expand irrigation-based agronomic production in particular areas of the country. This is the case of the so-called "Maize Triangle", an area with relatively high precipitation, underground water for irrigation and fertile soils that is demarcated by the towns of Grootfontein, Tsumeb, and Otavi 
in north-central Namibia [6]. The expansion of irrigation-based agronomic production is also planned for particular areas in north-central and north-eastern regions of the country by utilizing the Kunene, Kavango, and Zambezi rivers [6]. This proposed agricultural intensification and enlargement of fodder production areas at the expenses of relatively natural savanna ecosystems would have negative consequences for Namibia's grassland habitats that have already been intensified in the past and are influenced by grazing pressure and bush encroachment $[7,8]$. Cultivating crops for commercial purposes in these areas in the future would make it necessary to "prepare" the land, e.g., by shrubland clearing in order to create the necessary irrigation schemes [9]. However, the ecological consequences of such land conversion remain unclear. Considering the challenges to biodiversity and human well-being, the development of conceptual frameworks for a sustainable rangeland development in north-central Namibia is of great importance [10-12].

While the ecological consequences of a conversion of African savannas into arable land are still poorly understood (see above), the consequences of an increasing grazing pressure, especially in association with livestock farming, have been studied on several occasions. Many authors emphasized that livestock farming strongly influences vegetation and leads to severe anthropogenic-induced degradation of rangeland ecosystems [13,14]. Thus, changes in rangeland conditions are most likely reflected by changes in the vegetation, such as a large-scale conversion of grasslands into shrublands [7,15], which has been observed in many African savanna regions over previous years [2,16]. Vegetation parameters are often used to illustrate land use changes. In addition to vegetation-related changes, it is important to look at less visible parameters driving ecosystem alterations [10]. Therefore, the relations between land use and biodiversity have been studied using different animal taxa [10,17-19]. Large mammals are important regulators of processes within savanna ecosystems [20-23] and have been investigated in terms of their responses to land use-induced disturbances [24]. However, terrestrial small mammals, such as rodents, can have equally important key functions as primary consumers of plant biomass, distributors of seeds, prey animals for other species and indicators for changing abiotic factors through burrowing and impact on nutrient recycling [25]. Environmental changes alter small mammal habitat conditions and quickly affect their abundance, survival and reproductive success [26]. Thus, small mammals can be used as indicators for environmental conditions, providing a valuable context to evaluate land use induced faunal changes [27-29]. Moreover, due to this important ecological function in savanna ecosystems, particular small mammal species could become useful to monitor and indicate ecosystem changes following agricultural intensification. However, several studies suggest that population responses seem not consistent among species and geographical locations. Moreover, the impact of land use changes may not only be a result of the conversion of savannas into arable land, but also the result of the introduction of foreign crop species [30]. While improving the yield and nutritional quality of forage crops through the introduction of allochthonous crop species or varieties from other countries, it is likely that some rodent species might develop their full potential as harmful pest species [31,32], finally affecting overall small mammal species composition and community structure. Rodent-related damage to cereal crops remains a chronic problem for many small-scale farmers in Africa [33] and it is problematic from both an economical and a public health perspective [34,35].

Against this background, the overall objective of our study was to investigate and compare the response patterns of small mammal communities to increasing land use intensity within two different areas in northern Namibia: farmland at the southern boundary of Etosha National Park vs. farmland in Tsumeb agricultural area. Each area represents a different degree of landscape transformation and a different nature of increasing land use intensity (grazing pressure vs. conversion into arable land). We applied this comparative approach to investigate, whether the respective small mammal communities show similar or case-specific response patterns towards increasing land use intensity. The degree of similarity or case-specificity of response patterns towards land use intensity has far-reaching implications for the development of management measures concerning savanna ecosystems. Moreover, the comparative approach might help to identify particular species of special 
importance, either because those species can be used as ecological indicators for land use-related environmental changes or because those species can pose a threat to the environment under certain conditions of land use intensity. The central question is how to adopt sustainable agricultural practices in fragile arid and semi-arid savanna ecosystems. Using terrestrial small mammals—an important functional group within savanna ecosystems-as parameters of ecological stability or vulnerability, we aim to assess the sustainability of different agricultural practices (wildlife and livestock grazing, crop farming) in different areas of northern Namibia.

\section{Materials and Methods}

\subsection{Study Region and Research Areas}

The study region is situated in the dry bushland savanna of north-central Namibia and belongs to the Karstveld savanna biome [36]. The landscape is composed of a matrix of commercial farmland, which underwent a visible transformation process due to small-scale cropland expansion, increased grazing, altered fire frequency and land-use pressure [37]. However, theses landscapes provide numerous border habitats with remnants of the original flora and associated important ecosystem goods and services. Most importantly, the fenced Etosha National Park is exerting an influence on the surrounding landscape at several spatial scales and different ecological levels $[11,12,38]$.

Within this region, field research has been conducted in two different areas within the same homogenous eco-floristic and bioclimatic extent of the bushland savanna biome: (1) farmland adjacent to Etosha National Park (ENP) and (2) Tsumeb agricultural area. The farmland at the south-western border of the neighboring ENP (1) is administratively part of the Kunene region $\left(19.563^{\circ} \mathrm{S}, 14.031^{\circ} \mathrm{E}\right)$, whereas Tsumeb agricultural area (2) is situated approx. $100 \mathrm{~km}$ from the eastern part of ENP in the Oshikoto region $\left(19.2443^{\circ} \mathrm{S}, 17.7281^{\circ} \mathrm{E}\right)$. Both study areas lie on Karstveld, a massive deposit of calcrete and dolomites that represents the former remnant of Owambo basin folded upwards during the formation of ancient Gondwanaland. Two broad geological substrates mainly characterize the geological features and the soil characteristics: (1) loam-clay and (2) dolomite sands from the underlying rock formations [36]. Almost the entire study region comprising these two study areas can be characterized as arid to semi-arid savanna with $250-500 \mathrm{~mm}$ of average annual rainfall and a strong seasonality and high variability in years and timing. As is typical in this region, rainfall occurs during the summer months (between October and April) but more frequently peaking between February and April [36]. The region generally experiences a single dry season from May to November. The coolest months of the year are June and July with mean lowest night-time temperatures of $7{ }^{\circ} \mathrm{C}$. The main vegetation consists of shrub and thornbush savanna characterized by the coexistence of woody and herbaceous communities with differing phenological cycles (diverse semi-deciduous tree species, partly open grassland). The dominant woody plants are Colophospermum mopane trees and shrubs, Acacia species, Catophractes alexandrii, Terminalia prunioides and Combretum apiculatum woodland. Some areas suffer considerable bush encroachment by Dicrostachys cinerea. The grass layer in these rangelands is dominated by palatable species, which provide important grazing resources for livestock and game animals in the area. On the other hand, dominant perennial and annual grass species such as Anthephora pubescens, Digitaria eriantha, Cynodon dactylon, Cenchrus ciliaris, Aristida stipitata and Enneapogon cenchroides are common.

Land use on farmland at the south-western border of the ENP ranges from classical livestock farming to game farming in the form of eco-tourism, game meat production and/or trophy hunting. Major parts of the farmland are fenced, leading to locally high herbivore densities. Moreover, the creation of artificial watering points results in high populations and locally large aggregations of various herbivorous species, such as Tragelaphus strepsiceros, Phacochoerus africanus, Oryx gazella, Tragelaphus oryx, Antidorcas marsupialis, Equus zebra hartmannae and Connochaetes taurinus, so that there is a high grazing pressure by wild ungulates around the vicinity of available water [39]. Due to the fertile nature of the soil, the area around Tsumeb is one of the most important agricultural farming areas, dominated 
by several commercial small- and large-scale farming systems such as commercial livestock ranching, game farming, tourism and mixed cropping production (maize, lucerne, cotton and vegetables) under irrigation.

\subsection{Farm Management Practices and Site Selections}

The study region comprises a mosaic of arable farmland, cattle grazing farmland and semi-natural farmland. Data from private farmland bordering the ENP were collected at one site each of the following habitat types along a gradient of increasing land use intensity: near natural wildlife rangeland (WF1), wildlife rangeland close to an artificial waterhole (WF2), and livestock rangeland grazed by cattle (C) (Figures 1 and 2). Within the Tsumeb agricultural area, we selected two sites each on smallholder farmland representing the following land use types: livestock rangeland with encroaching bushland (EBL) and cleared bushland (CBL), and arable land with maize fields (MF), and lucerne fields (LF) (Figures 1 and 2). Three classes of land use intensity were distinguished in each study area: low, medium, and high. The definition of each class was based on the type of land use and the degree of anthropogenic transformation. The remote rangelands in the near-natural savanna ecosystem of the Etosha area were considered as areas with a low degree of anthropogenic transformation, whereas the populated rangelands and irrigated croplands of the Tsumeb area were considered as areas with a high degree of anthropogenic transformation. Based on this first classification, land use intensity in the Etosha area was considered as 'low' in the absence of any management, as 'medium' in the vicinity of an artificial waterhole with a high concentration of grazing wild ungulates, and as 'high' on the cattle grazing area. Land use intensity in the Tsumeb area was considered as 'low' within non-managed (bush encroached) cattle grazed rangelands, as 'medium' within cleared bushlands and as 'high' within irrigated arable monocultures. To minimize the influence of other environmental factors (e.g., micro-climate, soil properties), the sampling sites within the respective study areas were carefully selected to have similar topographic and soil characteristics.

a)

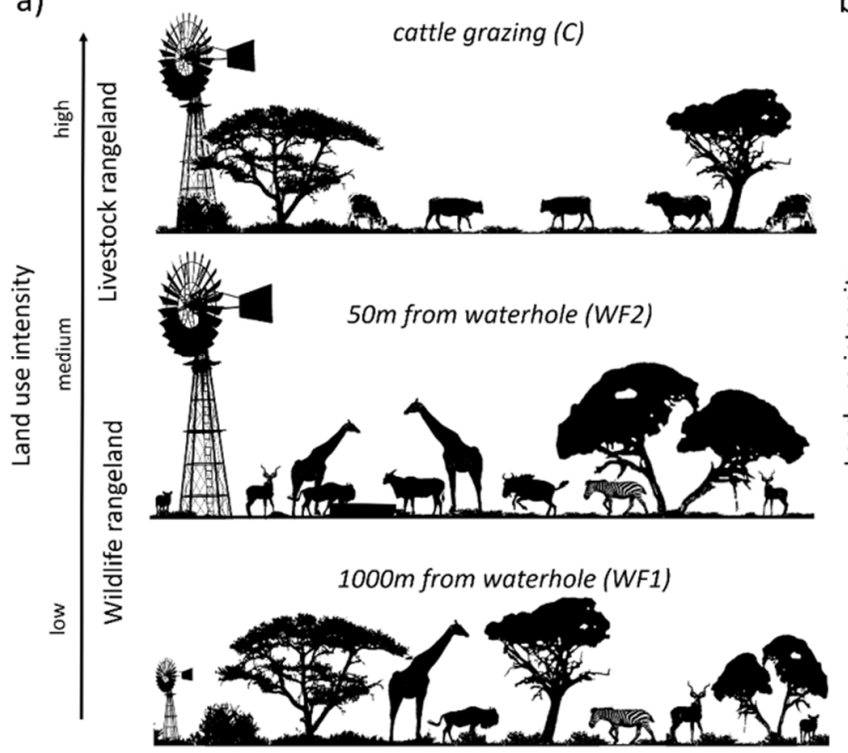

b)

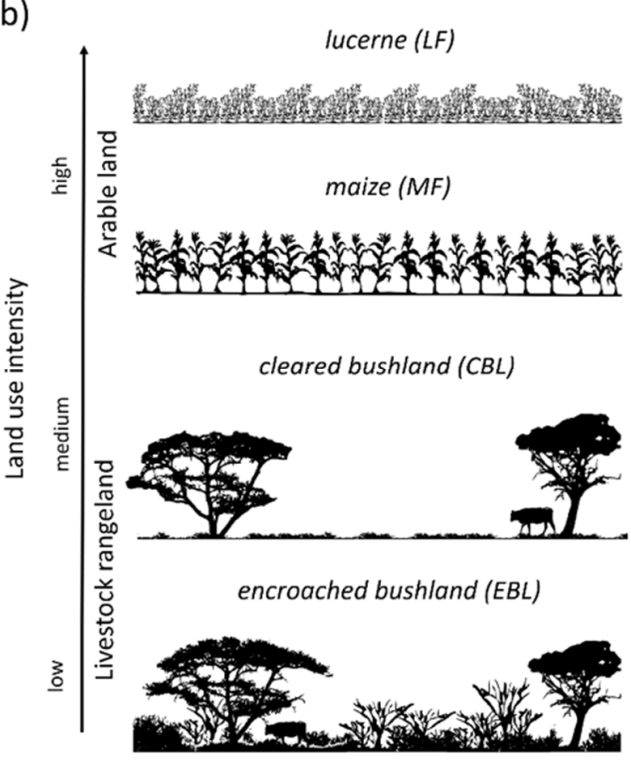

Figure 1. Study design: small mammal communities were investigated in three different habitat types (wildlife rangeland, livestock rangeland, arable land) with different land use intensities ('low' ,'medium', 'high') on (a) private farmland south of ENP (low anthropogenic transformation) and (b) smallholder farmland in Tsumeb agricultural area (high anthropogenic transformation). 


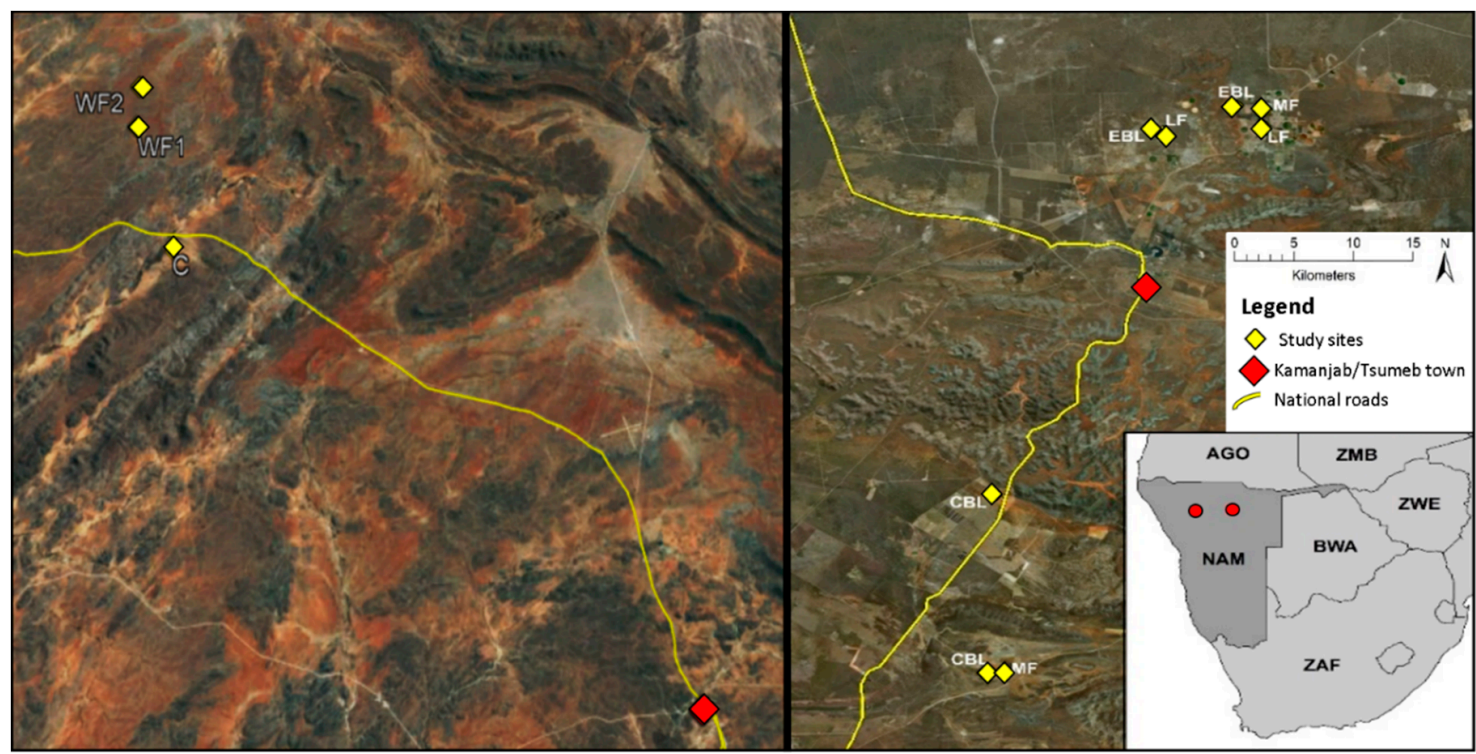

Figure 2. Location of the study areas (red circles in overview map) and sampling sites (yellow diamonds) in Namibia: (1) left-at the southern boundary of ENP near the city of Kamanjab and (2) right-around the city of Tsumeb; WF1/ WF2 = wildlife rangeland, wildlife rangeland in $1000 \mathrm{~m} / 50 \mathrm{~m}$ distance to waterhole; $\mathrm{C}=$ livestock rangeland grazed by cattle; $\mathrm{EBL} / \mathrm{CBL}=$ encroached bushland/cleared bushland, $\mathrm{MF} / \mathrm{LF}=$ maize/lucerne field.

\subsection{Small Mammal Sampling}

Small mammals were trapped using 100 (farmland south of ENP) and 90 (Tsumeb area) Sherman standard live traps, respectively, on each site spaced at $10 \mathrm{~m}$ intervals arranged in rows with 10 traps per row within a trapping quadrat (grid). In order to minimize patchiness and possible fragmentation of the study sites (to avoid the grid spanning over several habitat types) and enable obtaining habitat-specific estimates, specific site selection for grid establishment was based on prior subjective assessment. Traps were baited with a mixture of peanut butter, water and oats following Hoffmann and Zeller [27] and checked every morning. In each study, we performed trapping sessions for 4 consecutive nights $[40,41]$. In the Etosha area, we conducted four trapping sessions per study site from July to November in 2006 (4800 trap nights). In the Tsumeb agricultural area, we conducted two trapping sessions per study site in March 2017, Nov 2017, February 2018, May 2018, and December 2018 (3570 trap nights). Handling of captured animals was done in accordance with the Guidelines from the American Society of Mammalogists [42]. Animals were carefully removed from the live trap into a tube of acrylic glass for short-term immobilization for identification. Several external characteristics and measurements were used for species identification including shape of the body, weight, color, fur patterns, total length, tail length, ear length, right hind foot length. Small mammal species that could not be identified at the species level were identified at the genus level. After species identification, captured animals were released at the point of capture. Furthermore, voucher specimens of questionable individuals were retained as a reference for further taxonomic identification at the National Museum of Namibia. During the study conducted in the Etosha area, captured animals were colour-marked to identify recaptured individuals in order to estimate species abundance, diversity, and evenness.

\subsection{Data Analysis}

To understand how small mammal communities change across land use types and management practices, we estimated different community parameters: species richness (S) was defined as the total number of species captured per study site. Diversity was calculated using the Shannon diversity index 
$\left(\mathrm{H}=-\sum \mathrm{pi} \times \ln (\mathrm{pi})\right.$, where pi represents the proportion of individuals from species ' $\mathrm{i}$ ' [43]) with the software PAST [44]. Shannon's equitability $\left(\mathrm{E}_{\mathrm{H}}\right)$ was calculated to measure the evenness of small mammal communities $\left(\mathrm{E}_{\mathrm{H}}=\mathrm{H} / \mathrm{H}_{\max }=\mathrm{H} / \mathrm{lnS}\right)$.

The relative abundance of species captured in the Etosha area was assessed using the total number of captured individuals (excluding recaptures) divided by the number of trap nights. Data were converted to individuals per 100 trap nights $[45,46]$. We compared this index of relative abundance with a catch-effort index, the relative capture index (RCI), which gives the frequency of captures per trap per night. This index is a simple comparative trapping frequency index that can be used as an alternative to the relative abundance $[47,48]$. We calculated the RCI for each species as the number of captures divided by the total number of trap nights and converted this as per 100 trap nights to facilitate comparisons among habitat types within and between the two study areas, Etosha and Tsumeb. In order to validate the use of this index as an indirect measure of relative abundance, we compared the RCI with the relative abundance index from the Etosha data and performed a Spearman-rank correlation to assess the relationship between relative abundance and RCI. There was a strong positive correlation between relative abundance and the RCI, which was statistically significant ( $\mathrm{rs}=0.97$, $\mathrm{df}=16 p<0.001, \mathrm{z}=0.472_{0.05}$, Figure S1), suggesting that the RCI can be used as a valid proxy for the relative abundance of small mammals. For this reason and in order to compare the data from both study areas, we refer to the RCI as an indirect measure of relative abundance in the further course of the manuscript. Furthermore, the relationship between ecological parameters RCI and $S$ was investigated by plotting the total values of the calculated RCI and species richness (total number of species summed over all sample nights) for each site using Microsoft Excel. As the study design implies repeated measures, we controlled for experimental variability and evaluated temporal and spatial effects on mean RCI and S using one-way ANOVA (Geißer-Greenhouse correction), a Friedman test, a two-sample t-Test or a two-sample Kolmogorov-Smirnov (K-S) test, depending on the type and distribution of the data. Data were tested for normality (Shapiro-Wilk test) and homogeneity of variance (Levene's Test). The minimum level of significance for all tests was 0.05 . We conducted all statistical tests using GraphPadPrism version 9.0.0 for Windows (GraphPad Software, La Jolla, CA, USA, www.graphpad.com)

\section{Results}

\subsection{Etosha Area}

We captured nine species in total in the Etosha area, of which three were captured on all three study sites: Micaelamys namaquensis (Smith, 1834), Elephantulus intufi (Smith, 1836) and Gerbilliscus leucogaster (Peters, 1852) (Table 1). Whereas the RCI and species diversity were similar on the two wildlife rangeland sites, reduced values of these parameters were recorded on livestock farmland (Table 1 and Table S1). Species richness (S) was highest at the site with medium land use intensity (wildlife rangeland site close to the waterhole; $S_{\mathrm{WF} 2}=9$ ) and similar between the two other sites (low and high land use intensity; $S_{W F 1}=4$ and $S_{C}=5$ ). Except for site WF2 (medium land use intensity), there was no statistically significant effect of time (variability between trapping sessions) on mean RCI or S (Table S2). On site WF2, mean RCI and species richness were significantly lower during the first trapping session, compared to the mean RCI and species richness of the following three trapping sessions. 
Table 1. Summary of trapping data (total number of captures per species across all trapping sessions) from study sites on private farmland at the southern Etosha boundary; changes in species' capture frequency of $\geq 50 \%$ between classes of land use intensity are highlighted in bold. RCI-relative capture index based on number of captures per 100 trap nights. WF1/WF2-near-natural wildlife rangeland/wildlife rangeland close to artificial waterhole, $\mathrm{C}$ - cattle farm.

\begin{tabular}{|c|c|c|c|c|c|c|}
\hline & \multicolumn{4}{|c|}{ Wildlife Rangeland } & \multirow{2}{*}{\multicolumn{2}{|c|}{$\begin{array}{c}\text { Livestock Rangeland } \\
\text { C }\end{array}$}} \\
\hline \multirow{4}{*}{$\begin{array}{l}\text { land use intensity } \\
\text { trap nights } \\
\text { species }\end{array}$} & \multicolumn{2}{|c|}{ WF1 } & \multicolumn{2}{|c|}{ WF2 } & & \\
\hline & \multicolumn{2}{|c|}{ low } & \multicolumn{2}{|c|}{ medium } & \multicolumn{2}{|c|}{ high } \\
\hline & \multicolumn{2}{|c|}{1600} & \multicolumn{2}{|c|}{1600} & \multicolumn{2}{|c|}{1600} \\
\hline & captures & RCI & captures & $\mathrm{RCI}$ & captures & RCI \\
\hline Crocidura sp. & & & 1 & 0.062 & & \\
\hline Dendromus melanotis & & & 1 & 0.062 & & \\
\hline Elephantulus intufi & 25 & 1.56 & 50 & 3.12 & 26 & 1.63 \\
\hline Gerbilliscus leucogaster & 245 & 15.31 & 148 & 9.25 & 1 & 0.06 \\
\hline Micaelamys namaquensis & 284 & 17.75 & 23 & 1.44 & 174 & 10.88 \\
\hline Mus indutus & 195 & 12.19 & 455 & 28.44 & 34 & 2.125 \\
\hline Saccostomus campestris & & & 1 & 0.06 & & \\
\hline Steatomys parvus & 4 & 0.25 & 41 & 2.56 & & \\
\hline Thallomys nigricauda & & & 1 & 0.06 & & \\
\hline total & 753 & 47.06 & 721 & 45.06 & 235 & 14.69 \\
\hline
\end{tabular}

Moreover, we detected species-specific response patterns to land use intensity: the RCI of G. leucogaster continuously decreased from low land use intensity (non-disturbed wildlife rangeland) to high land use intensity (livestock farmland), where this species was captured only once. In contrast, the RCI of Mus indutus (Thomas, 1910) increased from low land use intensity (non-disturbed wildlife rangeland) to medium land use intensity (wildlife rangeland close to the waterhole). On livestock farmland, however, $M$. indutus revealed a reduced RCI. Likewise, E. intufi showed a similar pattern but the decrease in the RCI on livestock farmland was not as pronounced as for M. indutus. M. namaquensis was most abundant on non-disturbed wildlife rangeland. With medium land use intensity, we observed a decrease in the RCI of this species, however, followed by a tenfold increase with high land use intensity.

\subsection{Tsumeb Area}

Out of eight species captured in the Tsumeb area, the three species Mastomys natalensis (Smith, 1834), Aethomys crysophilus (de Winton, 1897) and G. leucogaster were represented across all investigated habitat types (Table 2). M. natalensis was the dominant species across all but one trapping site. The remaining five species were exclusively associated with bushland but not with arable land. Dendromus melanotis (Smith, 1834) and Crocidura sp. have been captured only once. Species richness and community composition were comparable between sites with low and medium land use intensity, while capture frequency strongly decreased. In contrast, species richness decreased from medium to high land use intensity (transition from livestock rangeland to arable land), while overall capture frequency strongly increased. Except for the habitat type EBL (low land use intensity), there was no statistically significant effect of time (variability between trapping sessions) or landscape (variability between sites) on mean RCIs or mean species richness (Table S3). On encroached bushland, a significant difference in the mean RCI between the trapping sessions of site 1 was determined (February 2018 and December 2018, Table S3). 
Table 2. Summary of trapping data (total number of captures per species across all trapping sessions) from study sites in Tsumeb agricultural area; changes in species' capture frequency of $\geq 50 \%$ between classes of land use intensity are highlighted in bold; RCI-relative capture index based on number of captures per 100 trap nights. $\mathrm{EBL} / \mathrm{CBL}=$ encroached/cleared bushland; $\mathrm{MF} / \mathrm{LF}=$ maize/lucerne field.

\begin{tabular}{|c|c|c|c|c|c|c|c|c|}
\hline & \multicolumn{4}{|c|}{ Livestock Rangeland } & \multicolumn{4}{|c|}{ Arable Land } \\
\hline & \multicolumn{2}{|c|}{ EBL } & \multicolumn{2}{|c|}{ CBL } & \multicolumn{2}{|c|}{ MF } & \multicolumn{2}{|l|}{ LF } \\
\hline land use intensity & \multicolumn{2}{|c|}{ low } & \multicolumn{2}{|c|}{ medium } & \multicolumn{2}{|c|}{ high } & \multicolumn{2}{|c|}{ high } \\
\hline trap nights & \multicolumn{2}{|c|}{990} & \multicolumn{2}{|l|}{990} & \multicolumn{2}{|c|}{630} & \multicolumn{2}{|c|}{960} \\
\hline species & captures & RCI & captures & RCI & captures & RCI & captures & RCI \\
\hline Aethomys crysophilus & 26 & 2.62 & 7 & 0.71 & 61 & 9.68 & 138 & 14.38 \\
\hline Crocidura sp. & 2 & 0.2 & & & & & & \\
\hline Dendromus melanotis & & & & & 1 & 0.16 & & \\
\hline Elephantulus intufi & 8 & 0.81 & 3 & 0.3 & & & & \\
\hline Gerbilliscus leucogaster & 180 & 18.18 & 17 & 1.71 & 18 & 2.86 & 20 & 2.08 \\
\hline Mastomys natalensis & 150 & 15.15 & 94 & 9.49 & 253 & 40.15 & 272 & 28.34 \\
\hline Mus sp. & & & 8 & 0.8 & & & & \\
\hline Steatomys pratensis & 18 & 1.82 & 18 & 1.82 & & & & \\
\hline indet. & 24 & & 21 & & & & & \\
\hline total & 408 & 41.21 & 168 & 16.96 & 333 & 52.85 & 430 & 44.79 \\
\hline
\end{tabular}

The response patterns of $M$. natalensis and $A$. crysophilus to land use intensity seemed similar: in both species, the RCI was lower on cleared bushland (medium land use intensity) compared to encroached bushland (low land use intensity) but increased on the arable land sites (high land use intensity). However, while for M. natalensis the RCI was about twice as high on the maize fields compared to lucerne fields, the RCI of $A$. crysophilus showed a threefold increase from maize to lucerne.

\subsection{Cross-Area Comparison}

The results point towards different patterns of small mammal responses to land use intensity in the two study areas (Figure 3). In the comparatively less disturbed Etosha area, species richness increased with medium land use intensity, while overall capture frequency remained constant. However, at the transition from wildlife rangeland to livestock rangeland (from medium to high land use intensity), a reduced capture frequency and a decrease in species richness to the initial level was observed. In the agriculturally heavily influenced Tsumeb area, on the other hand, there was initially no change in the number of species with increasing land use intensity, although a measurable reduction in small mammal capture frequency was observed on cleared bushland. With continuing land use intensity-at the transition from livestock rangeland to arable land—species richness declined, coupled with a marked increase in overall capture frequency. 


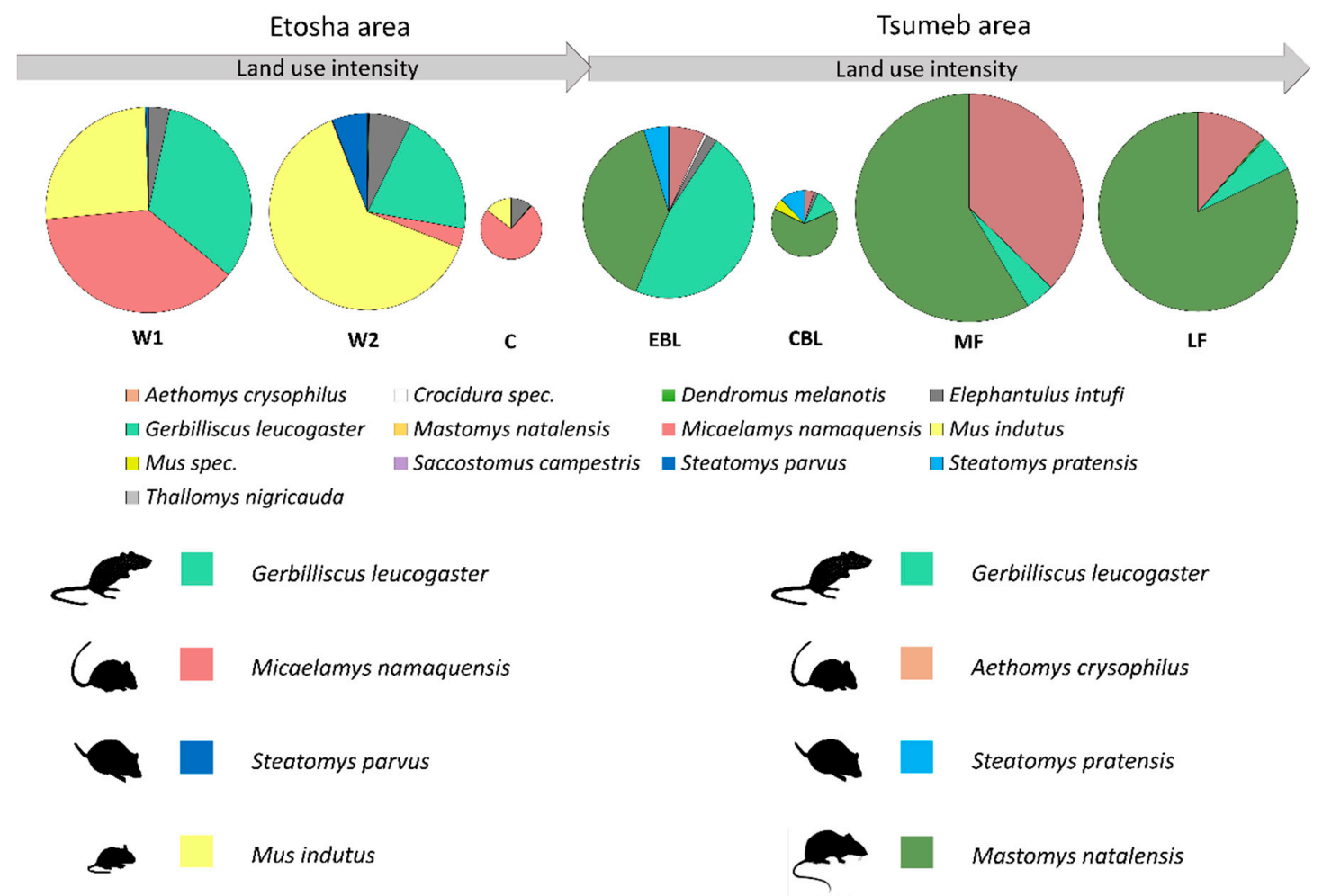

Figure 3. Species composition and capture frequency (RCI-captures/100 trap nights) along two gradients of land use intensity in the two study areas. Size of pie charts relates to total RCI values. WF1/WF2 = wildlife farmland $1000 \mathrm{~m} / 50 \mathrm{~m}$ distance from waterhole, $\mathrm{C}=$ cattle farm, EBL/CBL = cattle grazing on encroached/cleared bushland; $\mathrm{MF} / \mathrm{LF}=$ maize/ lucerne field. Species responding with changes in capture frequency of $\geq 50 \%$ between classes of land use intensity are shown below (G. leucogaster, M. namaquensis, A. crysophilus, S. parvus, S. pratensis, M. indutus, M. natalensis).

Moreover, the relationship between the ecological parameters (relative capture index [RCI] and species richness [S]) and the intensity of land use in the two study areas was examined (Figure 4). In the less transformed area (Etosha area), increasing land use intensity led to a clear decrease in the RCI. In contrast, increasing land use intensity in the more transformed area (Tsumeb area) first led to a decrease in capture frequency, followed by a clear increase on the arable land sites. In the Etosha area, medium land use intensity (concentrated grazing by wild ungulates close to waterhole) first led to an increase and the highest overall value of measured species richness $(S=9)$, while further increasing land use intensity (cattle grazing) resulted in a decreased number of species $(S=4)$ comparable to the number of the site with low land use intensity $(S=5)$. Species richness on bushland sites in the highly transformed agricultural area of Tsumeb was slightly higher compared to bushland in the near-natural savanna ecosystem of the Etosha area but was clearly reduced from $S=6$ to $S=3$ with increasing land use intensity at the transition from cleared bushland to arable farmland (Figure 4). 
low anthropogenic transformation Etosha area
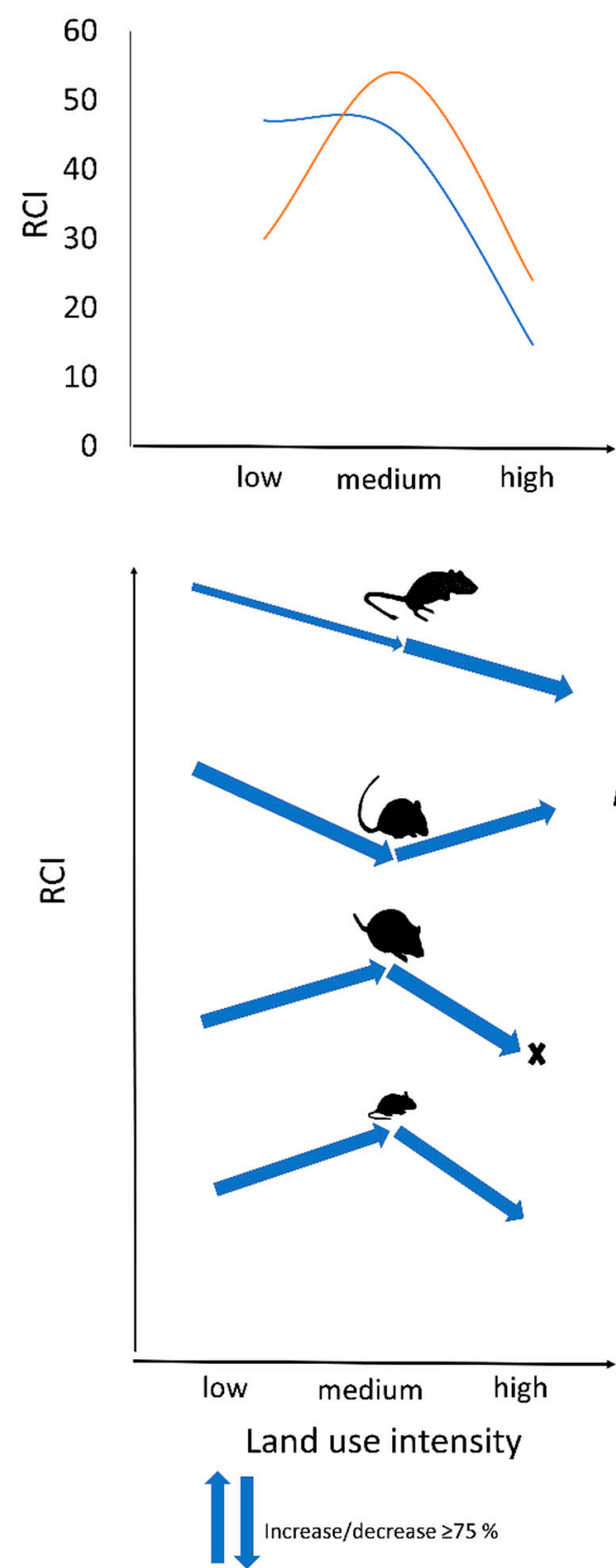

high anthropogenic transformation

Tsumeb area

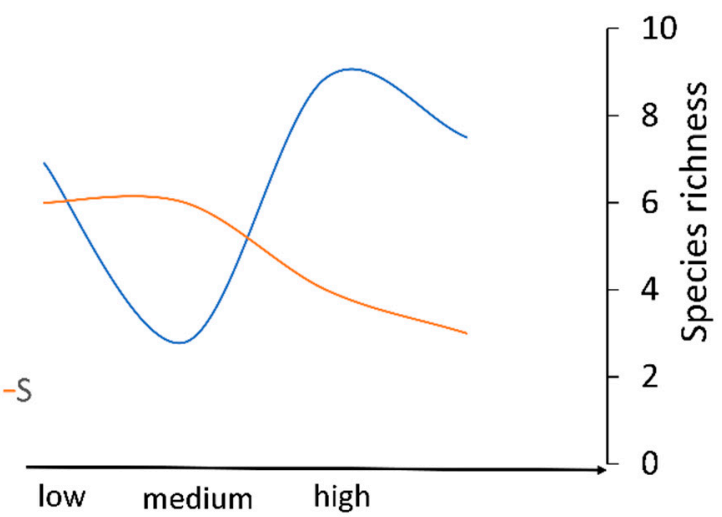

G. leucogaster

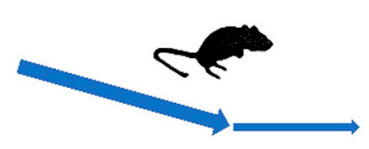

M. namaquensis/

A. crysophilus

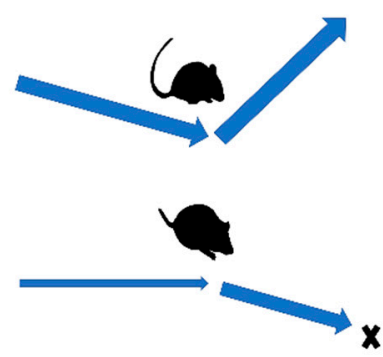

S. parvus/

S. pratensis

M. indutus

M. natalensis

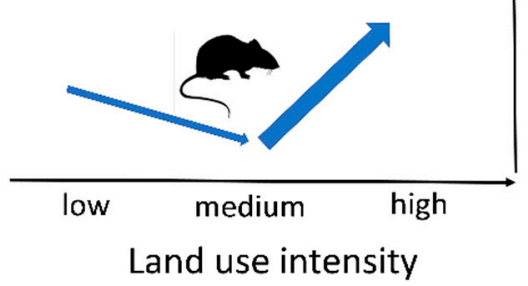

Increase/decrease $\geq 50 \% \quad \boldsymbol{X}$ species no longer present

Figure 4. Relationship between ecological parameters (total values of RCI and S) and schematic representation of response patterns of different small mammal species along gradients of land use intensity (low, medium, high) in the two study areas with different degrees of anthropogenic transformation (Etosha area, Tsumeb area).

\section{Discussion}

In this study, we investigate and compare the response patterns of small mammal communities to increasing land use intensity in two distinct areas in Namibia (Etosha vs. Tsumeb). Within each area, small mammal communities respond towards increasing land use intensity through changes in species richness and the relative capture index (RCI). After accounting for experimental variability and the effects of time and local landscape, we come to realize that the respective response pattern, however, differs between the two areas: in the Etosha area, a change from low to medium land use intensity 
is associated with an increase in species richness, while the overall RCI remains on a similar level. With the transition from medium to high land use intensity, species richness almost resembles the initial (low-intensity) value, while the overall RCI decreases. In the Tsumeb area, by contrast, a change from low to medium land use intensity does not affect species richness but leads to a decrease in the overall RCI. With the transition from medium to high land use intensity, the species richness in Tsumeb area decreases, while the overall RCI increases (Figure 4).

To understand these different response patterns, we have to consider the degree of landscape transformation, as well as the nature of land use change within the respective areas. In the Etosha area, the area of low land use intensity represents a relatively undisturbed savanna ecosystem-a wildlife farm bordering Etosha National Park in Namibia. As shown by Rottstock et al. [49], such wildlife farms can be regarded as examples of relatively undisturbed savanna systems. The transition from low to medium land use intensity results from increasing grazing pressure in close proximity to a waterhole (Figure 1). The increase in small mammal species richness corresponds to the concept of the Intermediate Disturbance Hypothesis [50]. Accordingly, a community's species richness initially increases when an undisturbed system is exposed to a moderate degree of disturbance. Further increasing the degree of disturbance, however, will lead to a decrease in species richness. In our study, accumulated wildlife grazing close to a waterhole induced a moderate disturbance that obviously enhanced structural complexity of the habitat and contributed to an increase in the species richness of the small mammal community. This effect became pronounced as the dry season progressed (Table S2): mean RCI and species richness were significantly higher during the trapping sessions 2-4 (Sept-Nov) compared to the first trapping session (July). In fact, this finding actually underlines the underlying biological effect of an increased species number resulting from medium land use intensity (WF2) when compared to low land use intensity (WF1): in the course of the dry season, the grazing pressure induced by increasing numbers of wildlife in the immediate vicinity of the waterhole apparently increased the disturbance in the course of our trapping sessions. The decrease in the overall RCI of the small mammal community under high land use intensity appears to be a result from an increased grazing pressure from livestock (Figures 3 and 4). This increased grazing pressure is accompanied by a reduction in the structural complexity (decrease in the degree of vegetation cover, soil compaction) and consequently the quality of the small mammal habitat.

This relationship between increasing grazing pressure and decreasing overall abundance of small mammal communities has been described in several previous studies [51-55]. The program BIOTA, a study in the Nama Karoo, clearly demonstrated that high grazing pressure significantly reduces the structural complexity of the habitat (vegetation cover and composition), and thus acts as a disruptive factor for small mammals $[27,29]$. Similar observations in a thornbush savanna area in Otjiamongombe or in south-eastern Kalahari Sandveld of Namibia's Omaheke Region (also within the BIOTA programme) support these findings: the authors showed that the abundance of small mammal communities on managed farmland is strongly positively correlated to vegetation cover $[28,55]$. Likewise, a study at Waterberg Plateau Park in Namibia confirms a decline in overall abundance of small mammal communities resulting from increasing grazing pressure [56]. Grazing can alter the structure and functions of grassland systems in many ways. In general, grazing leads to the removal of plant biomass and a decrease in vegetation height or coverage [57,58]. Moreover, selective feeding and trampling, especially by cattle, can change the abundance of different plant species and alter the composition and diversity of local plant communities $[59,60]$. Such alteration in vegetation structure can have pronounced impacts on small mammal communities, since it affects the availability of food and cover [61,62].

The above-mentioned studies consider the effect of increasing grazing pressure on small mammal communities. The situation in the Tsumeb area is different. Here, the increasing land use intensity results from the conversion of bushland to uniform and homogenous arable land. Unlike in the Etosha area, the initial situation in the Tsumeb area (bushland) does not represent a relatively natural system. Instead, the bushland habitat in the Tsumeb area is already the result of an anthropogenic-induced 
transformation process. Accordingly, our study sites in the Tsumeb area are characterized by a higher degree of transformation when compared to the study sites in the Etosha area. Not surprisingly, the overall RCI of the small mammal community on the cleared area is lower compared to the community on the bushland site, as the cleared area featured a lower level of structural complexity of the habitat. However, the species richness appears not affected by the clearing of bushland. In some way, this finding needs to be considered with care as there seems to be great variability between the trapping sessions on one of the two bushland sites (Table S3). However, a more important effect actually emerged at the transition from cleared bushland to arable land, namely the increase in the overall RCI and the decrease in species richness (Figures 3 and 4). This result was unaffected by effects of time or local landscape (Table S3). In the Tsumeb area, livestock production is continuously replaced by irrigation-based crop farming, involving the preparation of land through clearing of bushland. However, woody vegetation is an integral component of savannas and its removal implies a decrease in structural complexity. The transition from intermediate to high land use intensity-the conversion of cleared bushland into maize or lucerne fields-goes along with a reduction in structural complexity and floristic diversity of the habitat [63]. At this transition to arable land, we observed a decline in small mammal species richness, while the overall RCI increased substantially. Thus, it can be assumed that the structural homogeneity and uniformity of arable land leads to a break-up of a relatively complex small mammal community, but provides favorable living conditions for the remaining species (i.e., M. natalensis and A. crysophilus), which occur in very high densities (see below).

Regardless of the different relationships between species richness and the RCI in the two areas (Figure 4), particular species within these communities show similar response patterns and it seems reasonable to take a closer look at the mechanisms behind these responses. The bushveld gerbil (G. leucogaster) is the only species that occurs in both areas and that also responds in both areas in a similar way: increasing land use intensity leads to a significantly decreasing RCI. In contrast with several other species, G. leucogaster does not benefit from the moderate disturbance in the Etosha area (medium-intensity site). Rather, the RCI constantly decreases with increasing land use intensity. It seems that the beneficial effects resulting from changes in structural complexity of the vegetation cannot outweigh negative effects associated with an increase in grazing pressure. Grazing pressure can lead to alteration of the soil and the sensitivity of G. leucogaster to increasing grazing pressure seems related to soil compaction. As a species that excavates complex burrow systems, G. leucogaster prefers deep and light sandy soils [64,65] (Table S4). Apparently, the decreased RCI of G. leucogaster-both under increasing grazing pressure in the Etosha area and under habitat conversion to monoculture cropland in the Tsumeb area-results from changes to the soil. Our results suggest that G. leucogaster can be used as an ecological indicator of ecosystem integrity and the condition of savanna landscapes. This assumption was already made by other authors $[27,56]$. Based on our data, we can confirm the validity of this proposed indicator species. G. leucogaster actually meets all suitability criteria that a useful indicator species should have, as defined by McGeoch: (a) a broad distribution range, (b) a specialization to clearly defined habitat requirements (in this case light and sandy soils), (c) easy taxonomic identification, (d) distinctive sensitivity to a specific environmental change (in this case soil degradation), (e) cost effectiveness, and (f) its response to a specific environmental change should resemble the response of other species [66]. It is important to note that the response towards soil compaction is linked with bioturbation [10] but also reproduction, since especially altricial species with prolonged lactation strongly depend on sufficient soil conditions to successfully reproduce under harsh environmental conditions [67] (Table S4).

Besides G. leucogaster showing a similar response pattern in both areas, certain vicarious species also respond in a similar way to increasing land use intensity. Interestingly, the low-intensity sites in both areas feature a species of fat mice-Steatomys parous Rhoads, 1896 in the Etosha area and Steatomys pratensis Peters, 1846 in the Tsumeb area. Both S. parous and S. pratensis disappear with high land use intensity. Fat mice are known for their strategy to increase their survival in times of limited food availability by storing fat $[64,68,69]$. This adaptation to changing food availability already implies a 
high sensitivity to changing environmental conditions. Similar to G. leucogaster, fat mice also depend on deep, sandy soils in order to construct deep burrows with several tunnels in which they can enter the torpor in times of limited food availability [64,70-72] (Table S4). Changes in food availability and soil degradation due to pasture (S. parvus) or monoculture (S. pratensis) seem to prevent these species from continuing their energy-saving survival strategy.

Another similarity between the communities in the two areas exists in view of M. namaquensis (Etosha area) and A. crysophilus (Tsumeb area). These species have a close phylogenetic relation, and M. namaquensis was officially listed under the name Aethomys namaquensis (Smith, 1834) until a few years ago $[73,74]$. Both species show a rat-like appearance and share similar ecological adaptations with regard to reproduction and nutrition (Table S4). They are comparatively flexible in their habitat requirements and, in the event of severe disturbance, can apparently benefit from the disappearance of other species and become dominant species of the respective community owing to the lack of interspecific competition $[64,75,76]$. Both species, but especially A. crysophilus, tend to have explosive population growths due to their reproductive biology (year-round, short gestational period) $[75,76]$. Moreover, these species can make use of already existing burrows and are not dependent on particular soil conditions, as is the case for the bushveld gerbil or fat mice (see above) [73,74].

In addition to these three examples of similar response patterns of species within the two communities, we also observed area-specific response patterns of particular species. In the Etosha area, this is the case of $M$. indutus. In contrast to the bushveld gerbil (see above), M. indutus obviously benefits from the change in habitat heterogeneity associated with a moderate degree of disturbance. With a high degree of disturbance, however, the RCI of $M$. indutus significantly decreases. This is not surprising, since M. indutus tends to avoid open habitats [64] and would be forced to cover long distances without shelter from vegetation on the high-intensity site (cattle farm). However, the decreased RCI on the cattle farm might also be a result of the reduced availability of grasses, as $M$. indutus depends on a sufficient grass layer to construct grass nests in shallow burrows for reproduction (Table S4) [64]. In the Tsumeb area, an important response pattern was found for $M$. natalensis. This species shows a remarkable increase in the RCI on arable land, where it becomes the dominant species. M. natalensis is the most widespread rodent species in Africa and colonizes a variety of different habitats [77,78]. Its broad distribution range already indicates a wide ecological plasticity and underlines the role of $M$. natalensis as a pioneer species in the colonization of areas following agricultural (over-)utilization [79]. It is known that favorable environmental conditions (e.g., extended rainfall, phytohormones of sprouting vegetation) can trigger the reproductive activity in M. natalensis [80-82] (Table S4). Not surprisingly, M. natalensis can displace and outcompete other species [81]. Consequently, we found the decreasing RCI of G. leucogaster to be coupled with an increasing RCI of M. natalensis. This finding is supported by observations in Waterberg Plateau Park [56]. The competitive advantage of M. natalensis is linked with the species' life history, particularly its reproductive strategy. As a highly r-selected species, M. natalensis populations can exceed high numbers within a short period of time [79]. Its reproductive strategy is characterized by a high litter size (11-13 young/litter) in combination with a high number of litters per year (up to four litters), a short interval between litters, and a relatively early age at which breeding starts [80]. Furthermore, M. natalensis is a distinct food opportunist that feeds on what is available, but prefers seeds and cereals [79]. Therefore, irrigation-based cropping systems may particularly increase the resources available for M. natalensis and it seems reasonable that several generations of this species can survive in a newly established agricultural system. The explosive population growth of this species can be problematic, since it is involved in damages to a large number of cereal crops in southern Africa $[81,83]$ and is considered a main reservoir for important zoonoses such as Lassa virus, Lyme disease, or plague. However, despite its occurrence throughout Southern Africa, M. natalensis has not been captured in the Etosha area. One reason could be that this species nowadays is almost always found in close association with humans in rural villages and surrounding cultivated fields and, less commonly, in sparsely populated grasslands [83]. In addition, Happold and 
Happold [84] demonstrated that the abundance of M. natalensis may be extremely patchy, with large numbers occurring in preferred habitats and almost no individuals in nearby habitats.

\section{Conclusions}

Our study reveals different response patterns of small mammal communities to increasing land use intensity in two distinct areas (Etosha area vs. Tsumeb area). Within the less-transformed Etosha area, the species richness remains relatively constant and small mammal communities respond to increasing land use intensity by shifts in species composition. This shift in species composition may already result in the weakening of some ecosystem functions such as bioturbation, seed dispersal and food supply for predators. The change in the overall RCI has the potential to further weakening these functions. Within the more-transformed Tsumeb area, the species richness decreases substantially, while the RCI of a few species increases dramatically. The conversion of bushland into irrigated arable land results in a break-up of a balanced small mammal community and the unhindered rise of a few pest species. Obviously, these different response patterns are linked with an area's degree of landscape transformation, the nature of land use change, as well as the ecological adaptations of involved species [85]. Gerbilliscus leucogaster shows a distinctive sensitivity to land use-related soil degradation in both areas, suggesting that this soil-dwelling species can be used as an ecological indicator of ecosystem integrity and the condition of savanna landscapes. Mastomys natalensis has the potential to become an important pest species when bushland is transformed into irrigated arable land. Our results highlight the importance of area-specific management measures for biodiversity conservation in savanna ecosystems. Given the role of small mammal communities in agricultural ecosystems, the maintenance of species richness and a balanced community structure is of great importance to protect biodiversity and to reduce the risk of uncontrolled population growth of pest species.

Supplementary Materials: The following are available online at http://www.mdpi.com/1424-2818/12/12/488/s1, Figure S1: Spearman correlation of relative abundance and relative capture index on the three study sites in the Etosha area. Table S1: Small mammals captured by species on private farmland at the southern Etosha boundary. Table S2: Effects of time (variability between trapping sessions) on RCI (mean \pm SEM) and S (mean \pm SEM) in the Etosha area. Table S3: Effects of time (variability between trapping sessions) and local landscape (variability between sites) on RCI (mean \pm SEM) and S (mean \pm SEM) in the Tsumeb area. Table S4: Comparison of selected biological and ecological traits of small mammal species captured in the study areas.

Author Contributions: Conceptualization, U.Z., T.G., N.S. and S.B.; methodology, U.Z., S.B., N.S. and T.G.; investigation, S.B., N.S. and O.K.M.; resources, U.Z., S.B. and N.S.; data curation, S.B., O.K.M. and N.S.; writing-original draft preparation, T.G., N.S., U.Z. and O.K.M.; writing-review and editing, N.S., T.G. and U.Z.; visualization, N.S. and T.G.; supervision, U.Z.; project administration, U.Z. and T.G.; funding acquisition, U.Z., T.G. and N.S. All authors have read and agreed to the published version of the manuscript.

Funding: This research was supported by the Zwillenberg-Tietz foundation.

Acknowledgments: We thank the Namibian Ministry of Environment and Tourism for the necessary collecting permits (Permit-No 1071/2006 and Permit-No 2138/2016). We gratefully acknowledge the landowners and farmers for granting access to the field sites and support during the surveys. We thank Seth Eiseb and the National Museum of Namibia for taxonomic verification of specimens. O.K.M. gratefully acknowledges financial support of visits to Humboldt-Universität zu Berlin by the Zwillenberg-Tietz foundation and the International Office of Humboldt-Universität zu Berlin.

Conflicts of Interest: The authors declare no conflict of interest. The funders had no role in the design of the study; in the collection, analyses, or interpretation of data; in the writing of the manuscript, or in the decision to publish the results.

\section{References}

1. Osborne, C.P.; Charles-Dominique, T.; Stevens, N.; Bond, W.J.; Midgley, G.; Lehmann, C.E. Human impacts in African savannas are mediated by plant functional traits. New Phytol. 2018, 220, 10-24. [CrossRef] [PubMed]

2. Ward, D. Do we understand the causes of bush encroachment in African savannas? Afr. J. Range Forage Sci. 2005, 22, 101-105. [CrossRef] 
3. Wingate, V.R.; Phinn, S.R.; Kuhn, N.; Bloemertz, L.; Dhanjal-Adams, K.L. Mapping decadal land cover changes in the woodlands of north eastern Namibia from 1975 to 2014 using the Landsat satellite archived data. Remote Sens. 2016, 8, 681. [CrossRef]

4. Newman, E.A. Disturbance Ecology in the Anthropocene. Front. Ecol. Evol. 2019, 7, 147. [CrossRef]

5. Ministry of Agriculture, Water and Rural Development. National Agricultural Policy. Available online: https: //www.atf.org.na/cms_documents/8f7-nationalagriculturalpolicy1995.pdf (accessed on 30 September 2020).

6. Ministry of Agriculture, Water and Forestry. Green Scheme Policy. Available online: https://www.npc.gov.na/ downloads/policies\%20by\%20year/2008/Green\%20Scheme\%20Policy.pdf (accessed on 30 September 2020).

7. Joubert, D.F.; Rothauge, A.; Smit, G.N. A conceptual model of vegetation dynamics in the semiarid highland savanna of Namibia, with particular reference to bush thickening by Acacia mellifera. J. Arid Environ. 2008, 72, 2201-2210. [CrossRef]

8. Stolter, C.; Joubert, D.; Schwarz, K.; Finckh, M. Impact of bush encroachment management on plant response and animal distribution. In Climate Change and Adaptive Land Management in Southern Africa-Assessments, Changes, Challenges, and Solutions; Biodiversity \& Ecology; Revermann, R., Krewenka, K.M., Schmiedel, U., Olwoch, J.M., Helmschrot, J., Jürgens, N., Eds.; Klaus Hess Publishers: Windhoek, Namibia; Göttingen, Germany, 2018; Volume 6, pp. 219-225.

9. Vushe, A.; Haimene, E.P.; Mashauri, D. Namibian land use changes and nutrient water quality of the Okavango River. Madr. J. Agric. Environ. Sci. 2014, 3, 219-239.

10. Zeller, U.; Starik, N.; Göttert, T. Biodiversity, land use and ecosystem services-An organismic and comparative approach to different geographical regions. Glob. Ecol. Conserv. 2017, 10, 114-125. [CrossRef]

11. Mannetti, L.M.; Göttert, T.; Zeller, U.; Esler, K.J. Expanding the protected area network in Namibia: An institutional analysis. Ecosyst. Serv. 2017, 28, 207-218. [CrossRef]

12. Mannetti, L.M.; Göttert, T.; Zeller, U.; Esler, K.J. Identifying and categorizing stakeholders for protected area expansion around a national park in Namibia. Ecol. Soc. 2019, 24, 5. [CrossRef]

13. Milton, S.J.; du Plessis, M.A.; Siegfried, W.R. A conceptual model of arid rangeland degradation. Bioscience 1994, 44, 70-76. [CrossRef]

14. Wesche, K.; Ronnenberg, K.; Retzer, V.; Miehe, G. Effects of large herbivore exclusion on southern Mongolian desert steppes. Acta Oecol. 2010, 36, 234-241. [CrossRef]

15. Jeltsch, F.; Milton, S.J.; Dean, W.R.J.; Van Rooyen, N. Analysing shrub encroachment in the southern Kalahari: A grid-based modelling approach. J. Appl. Ecol. 1997, 134, 497-1508. [CrossRef]

16. Teague, W.R.; Duke, S.E.; Waggoner, J.A.; Dowhower, S.L.; Gerrard, S.A. Rangeland vegetation and soil response to summer patch fires under continuous grazing. Arid Land Res. Manag. 2008, 22, 228-241. [CrossRef]

17. Macdonald, D.W.; Tattersall, F.H.; Service, K.M.; Firbank, L.G.; Feber, R.E. Mammals, agri-environment schemes and set-aside-What are the putative benefits? Mamm. Rev. 2007, 37, 259-277. [CrossRef]

18. Medan, D.; Torretta, J.P.; Hodara, K.; Elba, B.; Montaldo, N.H. Effects of agriculture expansion and intensification on the vertebrate and invertebrate diversity in the Pampas of Argentina. Biodivers. Conserv. 2011, 20, 3077-3100. [CrossRef]

19. Starik, N.; Göttert, T.; Heitlinger, E.; Zeller, U. Bat community responses to structural habitat complexity resulting from management practices within different land use types-A case study from north-eastern Germany. Acta Chiropt. 2018, 20, 387-405. [CrossRef]

20. Hobbs, N.T. Modification of ecosystems by ungulates. J. Wildl. Manag. 1996, 60, 695-713. [CrossRef]

21. Le Roux, X.; Abbadie, L.; Fritz, H.; Leriche, H. Modification of the Savanna Functioning by Herbivores. In Lamto; Ecological Studies; Abbadie, L., Gignoux, J., Le Roux, X., Lepage, M., Eds.; Springer: New York, NY, USA, 2007; Volume 179, pp. 185-198. [CrossRef]

22. Sinclair, A.R.E. Mammal population regulation, keystone processes and ecosystem dynamics. Philos. Trans. R. Soc. Lond. B Biol. Sci. 2003, 358, 1729-1740. [CrossRef]

23. Zeller, U.; Göttert, T. The relations between evolution and domestication reconsidered-Implications for systematics, ecology, and nature conservation. Glob. Ecol. Conserv. 2019, 20, e00756. [CrossRef]

24. Kinnaird, M.F.; O'Brien, T.G. Effects of private-land use, livestock management, and human tolerance on diversity, distribution, and abundance of large African mammals. Biol. Conserv. 2012, 26, 1026-1039. [CrossRef] 
25. Ostfeld, R.S.; Keesing, F. Pulsed resources and community dynamics of consumers in terrestrial ecosystems. Trends Ecol. Evol. 2000, 15, 232-237. [CrossRef]

26. Horváth, G.F.; Horvath, B.; Sali, N.; Herczeg, R. Community-level response to different human disturbances and land use of small mammals in two marshland habitat patches in Hungary. Arch. Biol. Sci. 2012, 64, 613-628. [CrossRef]

27. Hoffmann, A.; Zeller, U. Influence of variations in land use intensity on species diversity and abundance of small mammals in the Nama Karoo, Namibia. Belg. J. Zool. 2005, 135, 91-96.

28. Muck, C.; Zeller, U. Small mammal communities on cattle and game grazing areas in Namibia. Afr. Zool. 2006, 41, 1-9. [CrossRef]

29. Hoffmann, A.; Vohland, K.; Zeller, U. Overgrazing favours desert species-Differences in arthropod and small mammal communities of the twin sites Gellap Ost and Nabaos. In Biodiversity in Southern Africa. Patterns and Processes at Regional Scale; Schmiedel, U., Jürgens, N., Eds.; Klaus Hess Publishers: Windhoek, Namibia; Göttingen, Germany, 2010; Volume 2, pp. 239-244.

30. Palumbi, S.R. Humans as the world's greatest evolutionary force. Science 2001, 293, 1786-1790. [CrossRef]

31. Brown, P.R.; Huth, N.I.; Banks, P.B.; Singleton, G.R. Relationship between abundance of rodents and damage to agricultural crops. Agric. Ecosyst. Environ. 2007, 120, 405-415. [CrossRef]

32. Heroldová, M.; Tkadlec, E. Harvesting behaviour of three central European rodents: Identifying the rodent pest in cereals. J. Crop. Prot. 2011, 30, 82-84. [CrossRef]

33. Odhiambo, R.O.; Makundi, R.H.; Leirs, H.; Verhagen, R. Dietary selection in Mastomys natalensis (Rodentia: Muridae) in the maize agro-ecosystems of central and southwestern Tanzania. Mammalia 2008, 72, 169-177. [CrossRef]

34. Swanepoel, L.H.; Swanepoel, C.M.; Brown, P.R.; Eiseb, S.J.; Goodman, S.M.; Keith, M.; Kirsten, F.; Leirs, H.; Mahlaba, T.A.M.; Makundi, R.; et al. A systematic review of rodent pest research in Afro-Malagasy small-holder farming systems: Are we asking the right questions? PLoS ONE 2017, 12, e0174554. [CrossRef]

35. Taylor, P.J.; Downs, S.; Monadjem, A.; Eiseb, S.J.; Mulungu, L.S.; Massawe, A.W.; Mahlaba, T.A.; Kirsten, F.; Von Maltitz, E.; Malebane, P.; et al. Experimental treatment-control studies of ecologically based rodent management in Africa: Balancing conservation and pest management. Wildl. Res. 2012, 39, 51-61. [CrossRef]

36. Mendelsohn, J.; Jarvis, A.; Roberts, C.; Robertson, T. Atlas of Namibia: A Portrait of the Land and Its People; David Philip Publishers: Cape Town, South Africa, 2002.

37. Erkkilä, A. Living on the land: Change in forest cover in north-central Namibia 1943-1996. Silva Carelica 2001, 37, 1-118.

38. Göttert, T.; Zeller, U. Das Etosha Pufferzonenprojekt-ein Konzept zur Unterstützung der Bemühungen zur Anbindung des Etosha Nationalparks an das transnationale Netzwerk von Schutzgebieten im südlichen Afrika. Beitr. Jagd Wildforsch. 2008, 33, 283-292.

39. Noack, J.; Schwabe, F.; Göttert, T.; Starik, N.; Zeller, U. Investigations on the occurrence and relative abundance of large carnivores and their potential prey using camera traps and line transect sampling. In Land Use and Nature Conservation-Proceedings of the 2nd International Workshop of the Quality Network Biodiversity in Sub-Sahara Africa; Dannenberg, P., Göttert, T., Nduru, G., Zeller, U., Eds.; Arbeitsberichte des Geographischen Instituts der Humboldt-Universität zu Berlin: Berlin, Germany, 2012; Volume 175, pp. 60-61. ISBN 0947-0360. [CrossRef]

40. Jones, C.; McShea, W.J.; Conroy, M.J.; Kunz, T.H. Capturing mammals. In Measuring and Monitoring Biological Diversity: Standard Methods for Mammals; Wilson, D.E., Cole, F.R., Nicols, J.D., Rudran, R., Foster, M.S., Eds.; Smithsonian Institution Press: Washington, DC, USA, 1996; pp. 115-155.

41. Fraser, J.L.; Thompson, G.G.; Moro, D. Adequacy of terrestrial fauna surveys for the preparation of Environmental Impact Assessments in the mining industry of Western Australia. Ecol. Manag. Restor. 2003, 4, 187-192. [CrossRef]

42. Sikes, R.S. Animal Care and Use Committee of the American Society of Mammalogists. Guidelines of the American Society of Mammalogists for the use of wild mammals in research and education. J. Mammal. 2016, 97, 663-688. [CrossRef]

43. Krebs, C.J. Ecological Methodology; Addison Wesley Longman: Menlo Park, CA, USA, 1999; pp. $361-362$.

44. PAST: Paleontological Statistics Software Package for Education and Data Analysis. Available online: https://palaeo-electronica.org/2001_1/past/past.pdf (accessed on 30 September 2020).

45. Caughley, G. Analysis of Vertebrate Populations; John Wiley and Sons: Chichester, UK, 1977; p. $12 \mathrm{ff}$. 
46. Heroldová, M.; Bryja, J.; Zejda, J.; Tkadlec, E. Structure and diversity of small mammal communities in agriculture landscape. Agric. Ecosyst. Environ. 2007, 120, 206-210. [CrossRef]

47. Castañeda, I.; Pisanu, B.; Díaz, M.; Rézouki, C.; Baudry, E.; Chapuis, J.L.; Bonnaud, E. Minimising trapping effort without affecting population density estimations for small mammals. Mamm. Biol. 2018, 93, 144-152. [CrossRef]

48. Hopkins, H.L.; Kennedy, M.L. An assessment of indices of relative and absolute abundance for monitoring populations of small mammals. Wildl. Soc. Bull. 2004, 32, 1289-1296. [CrossRef]

49. Rottstock, T.; Göttert, T.; Zeller, U. Relatively undisturbed African savannas-An important reference for assessing wildlife responses to livestock grazing systems in European rangelands. Glob. Ecol. Conserv. 2019, 23, e01124. [CrossRef]

50. Osman, R.W. Intermediate Disturbance Hypothesis. In Encyclopedia of Ecology, 2nd ed.; Fath, B., Ed.; Elsevier: Amsterdam, The Netherlands, 2019; Volume 1, pp. 441-450. ISBN 9780444641304. [CrossRef]

51. Grant, W.E.; Birney, E.C.; French, N.R.; Swift, D.M. Structure and productivity of grassland small mammal communities related to grazing-induced changes in vegetative cover. J. Mammal. 1982, 63, 248-260. [CrossRef]

52. Avenant, P. Small mammal diversity in the Maguga Dam inundation area, Swaziland. S. Afr. J. Wildl. Res. 2002, 32, 101-108.

53. Prevedello, J.A.; Dickman, C.R.; Vieira, M.V.; Vieira, E.M. Population responses of small mammals to food supply and predators: A global meta-analysis. J. Anim. Ecol. 2013, 82, 927-936. [CrossRef] [PubMed]

54. Hauptfleisch, M.L.; Vinte, M.P.; Blaum, N. A comparison of the community dynamics of bioturbating small mammals between livestock and wildlife farming areas in the Kalahari, Namibia. J. Namibian Stud. 2017, 1, 34-39.

55. Muck, C.; Zeller, U. Kleinsäugerpopulationen zweier unterschiedlich genutzter Weideflächen in Namibia. In Treffpunkt Biologische Vielfalt IV; Korn, H., Feit, U., Eds.; Bundesamt für Naturschutz: Bonn, Germany, 2004; pp. 195-201.

56. Erckie, B.J. Assessing the Effects of Grazing Intensity by Large Herbivores on Species Diversity and Abundance of Small Mammals at Waterberg Plateau Park, Namibia. Master's Thesis, Humboldt-Universität zu Berlin, Germany and University of Namibia, Windhoek, Namibia, April 2007. Available online: http: //repository.unam.edu.na/handle/11070/342 (accessed on 12 March 2020).

57. Hickman, K.R.; Hartnett, D.C. Effects of grazing intensity on growth, reproduction, and abundance of three palatable forbs in Kansas tallgrass prairie. Plant Ecol. 2002, 159, 23-33. [CrossRef]

58. Rickart, E.A.; Bienek, K.G.; Rowe, R.J. Impact of livestock grazing on plant and small mammal communities in the Ruby Mountains, northeastern Nevada. West. N. Am. Nat. 2013, 73, 505-515. [CrossRef]

59. Burke, A. The impact of large herbivores on floral composition and vegetation structure in the Naukluft Mountains, Namibia. Biodivers. Conserv. 1997, 6, 1203-1217. [CrossRef]

60. Augustine, D.J.; McNaughton, S.J. Ungulate effects on the functional species composition of plant communities: Herbivore selectivity and plant tolerance. J. Wildl. Manag. 1998, 62, 1165-1183. [CrossRef]

61. Avenant, N.L.; Cavallini, P. Correlating rodent community structure with ecological integrity, Tussen-die-Riviere Nature Reserve, Free State province, South Africa. Integr. Zool. 2007, 2, 212-219. [CrossRef]

62. Bowland, A.E.; Perrin, M.R. The effect of overgrazing on the small mammals in Umfolozi Game Reserve. Z. Säugetierkd. 1998, 54, 251-260.

63. Munro, N.T.; Fischer, J.; Wood, J.; Lindenmayer, D.B. Revegetation in agricultural areas: The development of structural complexity and floristic diversity. Ecol. Appl. 2009, 19, 1197-1210. [CrossRef]

64. Skinner, J.D.; Chimimba, C.T. The Mammals of the Southern African Sub-Region; Cambridge University Press: Cambridge, UK, 2005.

65. du Plessis, J.; Swanepoel, L.H.; McDonough, M.; Schoeman, C. A conservation assessment of Gerbilliscus leucogaster. In The Red List of Mammals of South Africa, Swaziland and Lesotho; Child, M.F., Roxburgh, L., Do Linh San, E., Raimondo, D., Davies-Mostert, H.T., Eds.; South African National Biodiversity Institute and Endangered Wildlife Trust: Cape Town, South Africa, 2016.

66. McGeoch, M.A. The selection, testing and application of terrestrial insects as bioindicators. Biol. Rev. 1998, 73, 181-202. [CrossRef] 
67. Giere, P.; Zeller, U. Small mammal diversity and reproduction along a transect in Namibia (BIOTA S 07). In African Biodiversity. Molecules, Organisms, Ecosystems; Huber, B., Sinclair, J., Lampe, K.H., Eds.; Springer: Berlin, Germany, 2004; pp. 305-313.

68. Smithers, R.H.N.; Wilson, V.J. Check List and Atlas of the Mammals of Zimbabwe Rhodesia; Trustees of the National Museum of Rhodesia: Salisbury, Rhodesia, 1979.

69. Schlitter, D.; Monadjem, A. Steatomys parvus. The IUCN Red List of Threatened Species. IUCN 2017, e.T20721A22233188. [CrossRef]

70. Perrin, M.R.; Richardson, E.J. Factors affecting the induction of torpor and body mass in the fat mouse Steatomys pratensis. J. Therm. Biol. 2004, 29, 133-139. [CrossRef]

71. Child, M.F.; Monadjem, A. Steatomys pratensis (errata version published in 2017). The IUCN Red List of Threatened Species. IUCN 2016, e.T20722A115159593. [CrossRef]

72. Schoeman, C.; Relton, C.; Harvey, J.; Monadjem, A. A conservation assessment of Steatomys pratensis. In The Red List of Mammals of South Africa, Swaziland and Lesotho; Child, M.F., Roxburgh, L., Do Linh San, E., Raimondo, D., Davies-Mostert, H.T., Eds.; South African National Biodiversity Institute and Endangered Wildlife Trust: Cape Town, South Africa, 2016.

73. Cassola, F.; Child, M.F.; Coetzee, N. Micaelamys namaquensis (amended version of 2016 assessment). The IUCN Red List of Threatened Species. IUCN 2017, e.T573A114636514. [CrossRef]

74. Child, M.F. Aethomys chrysophilus (errata version published in 2017). The IUCN Red List of Threatened Species. IUCN 2016, e.T569A115050345. [CrossRef]

75. Russo, I.R.; MacFadyen, D.; Taylor, P.; Child, M.F. A conservation assessment of Micaelamys namaquensis. In The Red List of Mammals of South Africa, Swaziland and Lesotho; Child, M.F., Roxburgh, L., Do Linh San, E., Raimondo, D., Davies-Mostert, H.T., Eds.; South African National Biodiversity Institute and Endangered Wildlife Trust: Cape Town, South Africa, 2016.

76. Linzey, A.; MacFadyen, D.; Russo, I.M.; Taylor, P.; Bryja, J. A conservation assessment of Aethomys chrysophilus. In The Red List of Mammals of South Africa, Swaziland and Lesotho; Child, M.F., Roxburgh, L., Do Linh San, E., Raimondo, D., Davies-Mostert, H.T., Eds.; South African National Biodiversity Institute and Endangered Wildlife Trust: Cape Town, South Africa, 2016.

77. Massawe, A.W.; Mulungu, L.S.; Makundi, R.H.; Dlamini, N.; Eiseb, S.J.; Kirsten, F.; Mahlaba, T.; Malebane, P.; Von Maltitz, E.; Monadjem, A.; et al. Spatial and temporal population dynamics of rodents in three geographically different regions in Africa: Implication for ecologically-based rodent management. Afr. Zool. 2011, 46, 393-405. [CrossRef]

78. Eiseb, S.; Taylor, P.; Zeller, U.; Denys, C.; Nicolas, V. Rapid peripatric speciation linked with drainage evolution in a rare African rodent, Mastomys shortridgei (Rodentia: Muridae). J. Zool. Syst. Evol. Res. 2020. [CrossRef]

79. Mulungu, L.S.; Massawe, A.W.; Kennis, J.; Crauwels, D.; Eiseb, S.; Mahlaba, T.A.; Monadjem, A. Differences in diet between two rodent species, Mastomys natalensis and Gerbilliscus vicinus, in fallow land habitats in central Tanzania. Afr. Zool. 2011, 46, 87-392. [CrossRef]

80. Makundi, R.H.; Massawe, A.W.; Mulungu, L.S. Reproduction and population dynamics of Mastomys natalensis Smith, 1834 in an agricultural landscape in the Western Usambara Mountains, Tanzania. Integr. Zool. 2007, 2, 233-238. [CrossRef]

81. Leirs, H.; Verhagen, R.; Verheyen, W.; Mwanjabe, P.; Mbise, T. Forecasting rodent outbreaks in Africa: An ecological basis for Mastomys control in Tanzania. J. Appl. Ecol. 1996, 33, 937-943. [CrossRef]

82. Firquet, E.; Leirs, H.; Bronner, G. Germinating grasses and reproductive seasonality of Mastomys species (Rodentia, Muridae). Mammalia 1996, 60, 775-779.

83. Leirs, H. Population Ecology of Mastomys Natalensis (Smith, 1834); Implications for Rodent Control in Africa, Agricultural Edition; Belgian Administration for Development Cooperation: Brussels, Belgium, 1994; Volume 35, pp. 1-268. 
84. Happold, D.C.D.; Happold, M. An ecological study of small rodents in the thicket-clump savanna of Lengwe National Park, Malawi. J. Zool. 1991, 223, 527-547. [CrossRef]

85. Zeller, U.; Perry, G.; Starik, N.; Göttert, T. Organisms in Nature-Evolutionary Perspective and Ecological Significance; Humboldt-Universität zu Berlin: Berlin, Germany, 2020; pp. 3-7. [CrossRef]

Publisher's Note: MDPI stays neutral with regard to jurisdictional claims in published maps and institutional affiliations.

(C) 2020 by the authors. Licensee MDPI, Basel, Switzerland. This article is an open access article distributed under the terms and conditions of the Creative Commons Attribution (CC BY) license (http://creativecommons.org/licenses/by/4.0/). 